\title{
INSTITUTIONAL AND FUNCTIONAL FRAMEWORKS FOR CAPITAL MARKETS IN THE REPUBLIC OF SERBIA
}

\author{
Nataša Simić ${ }^{1}$, Dragana Božilović Djokić ${ }^{2}$, Vladimir Djokić ${ }^{3}$ \\ ${ }^{1}$ University Union Nikola Tesla, Faculty of Economics and Finance, Belgrade, Serbia \\ ${ }^{2,3}$ University Union Nikola Tesla, Belgrade, Serbia \\ nsimic68@gmail.com,draganadjokic74@gmail.com, vladimirdjokic001@gmail.com
}

\section{Professional Paper \\ 10.5937/jouproman9-29885}

\begin{abstract}
Globalization of financial flows, monetary integration, deregulation and cutting-edge information technology promote the growth of efficient capital market, as an integral part of national financial markets. The aim of this paper is to point out advantages and disadvantages of the development of relatively new capital market in the transition period of the Serbian economy. In the broadest sense, financial market is an organized place, where supply and demand for financial asset meet, forming the price of financial asset. In short, financial market includes all the institutions and procedures by which sellers and buyers of financial instruments are connected regardless of the nature of financial instrument. It enables unhindered funds and capital flow to the place where it can be employed most efficiently. Financial market development, depth and stability are crucial for economic growth and they are also a significant indicator of national market development in relation to its environment.
\end{abstract}

Key words: market, capital, transition, globalization, financial instruments

\section{Introduction}

One of the primary roles of capital markets is to provide for an optimum allocation of financial resources by balancing supply and demand, which achieves selective and allocative function of the market in terms of using money and capital. Accordingly, the most important functions of the capital market in the circumstances of the Republic of Serbia are as follows (Simoneti, M., Kawalec, S., 1995., p.35-37)

- The mobilization of domestic savings and accumulation and directing them towards the companies that have a budget deficit, but also have profitable projects.Reallocation of existing savings to securities on the capital market, either under direct control of investors or indirectly, (e.g. through investment funds) is expected to give a strong impetus to this market.

A more efficient reallocation of available accumulation is achieved by continuous monitoring of stock prices on the market and directing available funds to those who achieve great results due to a successful development policy. At the same time, small and medium enterprises get a chance to get the necessary funds for development by offering higher rates of return to potential investors, as compensation for the associated risk.An objective assessment of the reported business results and potential of these companies is a prerequisite for selection and their good positioning on the capital market. 
Commercial banks, as the dominant financiers of corporations in the previous period, due to numerous risks, and especially due to the fear of "melting" of the principal due to the present inflation, approved loans primarily for a short period, usually up to 30 days, with the possibility of extension. Corporations with good investment projects, whose shares are listed on the market, can obtain long-term funds by issuing and selling long-term (equity) securities. One of the conditions for investors to primarily buy long-term securities is that the secondary market of those securities is liquid, or, in other words, investors will buy long-term securities if they can sell their investment before its maturity, i.e. turn it back into cash.

Considering the basic assumption of the existence of a positive correlation between business efficiency (management) and stock prices, it is clear that effective corporate governance is crucial. In other words: the capital market eliminates all those who have no prospects. At the same time, the capital market could solve the burning problem of the RS economy, insufficiently effective management, by replacing the administrations that achieve poor results (or the result is a low price of shares on the market) with young, educated, ambitious, capable managers, i.e. people with an idea. Meanwhile, the market would create the price of a good manager.

The constitution of an active and efficient capital market can be a clear signal and stimulus to the arrival of foreign capital in the form of direct or portfolio investments.It goes without saying that there is a strong property and contractual security, clear property relations, effective regulation of political and economic stability, good information and the like.
Ensuring the liquidity of investments, which means the possibility of converting investments into cash in the short term, without significant deviations from the price. The continuity of the capital market is one of the assumptions of liquidity.Enabling the application of different investment strategies, according to the investor's affinities.

One of the tasks of any market, including the financial market, is to use the 'invisible hand' concept that describes social benefits of an individual's self-interested actions. Social life is impossible if the race to pursue one's own interests is not mitigated and others are shown respect and sympathy. A society made up of hard egoists would just break into pieces; (any real altruist would endure hardships. (Bernard J.Foley, 1991, p. 200.) Certainly the opposing interests that exist in financial market participants are conditio sine qua non for the market to exist at all, but for it to function successfully it is necessary that participants adhere to established rules. "Moreover, there must be a mechanism that will force each individual to abide by the rules, even when they are contrary to his immediate interests." (Robinson, J.1964, p. 10).

The development of the capital market and its stability largely depend on the adequacy of legislation and its implementation in practice. Legal regulations, necessary for the functioning of the financial market, can be grouped into three levels: (Erić, 1997, p. 45).

- Systemic laws from various areas that regulate relations related to the financial market (Law on Banks, Law on Companies, etc.). 
- Legal regulations that directly determine the area of the financial market (Law on the securities market, bylaws).

- Internal legal regulations, such as statutes, rules of procedure, codes, etc.

It seems that the Republic of Serbia has advanced the most in defining legal regulations related to this issue. This primarily refers to the enactment of numerous laws on the securities market, laws on companies, laws on banks, privatization, accounting and auditing, laws on corporate income tax, laws on value added tax, etc.

In addition to these legal regulations, bylaws adopted by the Securities Commission, the Stock Exchange and the Central Registry also play a significant role in regulating the capital market. The application of legislation should aim to provide full legal certainty and protection of participants in the capital market. Such relief significantly helps participants to concentrate on what they take sole responsibility for, and that is making an investment decision. Despite the assessment that a solid legal basis for the development of the primary and secondary market has been provided, the practice has shown that this was not a sufficient condition for the development of an efficient and liquid market. Legislation in the Republic of Serbia should be further upgraded in the area of securities business in order to encourage intensive development, more precise definition of participants' obligations, elimination of observed irregularities, implementation of better protection of participants from potential abuses and creation of preconditions for business of new participants in the financial market. A special task is the standardization and harmonization of legal regulations and its harmonization with the legislation of the European Union.

The harmonious functioning of the capital market largely depends on the supervision over the entire activities that take place in that market, starting from fulfilling the conditions of issuing securities and respecting the legality of their trading, to controlling the professional and ethical behavior of participants.

When it comes to the Republic of Serbia, the main role of supervising operations on the capital market is played by the Securities Commission, which was formed in February 1990 upon the request of the World Bank. The commission was constituted by a decree of the government, which regulated all relevant issues for its functioning and also determined its competence. According to the principles established by the International Organization of Securities Commissions (IOSCO), the Securities Commission should have the status of an independent, non-governmental, non-profit, professional institution, in a word, a status similar to that of central banks in many developed countries.

In addition to legally defined supervision, an important role in regulating the financial market is played by the so-calledselfregulatory organizations. The Stock Exchanges and Stock Brokers organization has existed in the Republic of Serbia for several years. 
However, despite evident efforts, it has failed to impose itself more seriously in practice, i.e.it was supposed to be a place meant for preparing and adopting bylaws, realizing further education, resolving disputes, taking measures against those who do not respect the rules of conduct(i.e. damage the reputation of the capital market), carrying out numerous activities in order to develop the market and build the reputation and trust of stockbrokers and the stock exchange.

As for the Republic of Serbia, the Law on Capital Market and Other Financial Instruments and bylaws of the Securities Commission determine the issue procedure, the content of the request, the necessary documentation, the content of the public invitation for subscription and purchase of shares (prospectus), as well as the procedure for conducting control by the Commission. for securities. The mentioned law stipulates that securities, except in exceptional cases, are issued, i.e. distributed through a public offering. At the same time, commercial banks, with which the issuer has a contract, are located as a place of subscription and payment, which makes it practically impossible for the primary sale of securities to be performed on the organized stock exchange market or the over-the-counter market.The Law on Companies stipulates that open joint stock companies may issue shares through open (public) or closed issue, which is only one of the issues due to which it is necessary to harmonize legal regulations. When it comes to the secondary capital market in the Republic of Serbia, it is regarded as rather underdeveloped and insufficiently liquid. Underdevelopment is primarily reflected in the presence of a small number of securities. Currently, only the shares issued in the privatization process and foreign currency savings bonds are traded on the capital market in the Republic of Serbia. The non-market way itself carries its negativities in terms of their attitude towards the financial market, its function and significance. The vast majority of current owners treat the capital market as a way to turn their "investments" into cash again, and not as place where they plan to stay longer and check their investment abilities. The absence of a wide range of other financial assets, such as long-term securities issued by the state, i.e. government, various state institutions, the absence of long-term corporate bonds and treasury securities, is one of the main limiting factors of market development.

Insufficient liquidity of the market is manifested through the inability to sell shares in the short term. Although there is a constant supply for shares of a number of issuers, there is no demand. Also, a supply is often higher than demand, which means that those who want to sell shares in the short term are forced to reduce the supply price by a significant amount, compared to the current market price. Only in exceptionally rare cases does the demand for shares exceed the supply, primarily if the shares are the ones with better performance. Until October 2004, only the periodic auction trading method was applied on the Belgrade Stock Exchange, and from mid-October of the same year, the continuous trading method was introduced. It can be said that the transition to this way of trading completely justified the expectations, since those shares are the most liquid part of the market. One of the reasons for the unsatisfactory liquidity of the market is the fact that in the Republic of Serbia, despite the legal possibility, no one plays the role of a market makerin practice. 
When it comes to emerging markets, such as the capital market in the Republic of Serbia, it is important that both the primary and secondary markets properly function due to their strong interconnectedness and conditionality. Primary markets cannot exist and develop in breadth and depth without a properly developed secondary market. On the other hand, the secondary market has a role to play in providing adequate prices and liquidity. The secondary stock market is a test of the success of investor assessments. As there is no such thing as a perfect market, which means that all participants are equally well informed, potential investors who are better informed, thus expecting a better "cash flow," will be willing to buy all available shares, or even to pay a better price than those who do not have that information.

In short: such behavior of investors is based on the assessment that the real value of these shares is higher than their market price, so it is realistic to expect the realization of capital gains in the future, when they are balanced.Such investor behavior would stimulate other investors to buy these shares, which would consequently raise the prices of these shares, thus bringing them closer to the real (internal) value.

One of the basic conditions for gaining trust on the capital market is to prevent trading in non-existent securities, i.e. securities that the seller does not own. This is especially important in the situation in the Republic of Serbia, which has opted for the issuance of securities in dematerialized form, as well as the dematerialization of already issued securities. Therefore, in order to ensure the safety of domestic and foreign investors, the following aspects are essential: clear precision in the procedures for keeping and recording the registration of securities, their verification before trading, as well as the transfer of ownership after trading. It is realized byadequate software, hardware, telecommunication technology and reliable data protection.

According to the rules of trading in shares from the privatization procedure on the Belgrade Stock Exchange, the buyer's stockbroker is obliged to provide coverage in the amount of $100 \%$. Before issuing the purchase order, the stockbroker must have a statement from the designated account, in order to prove that the funds have been provided, and a power of attorney to dispose of them. According to the currently valid regulations, prompt settlement after the purchase is performed within 3 days, from the day when the transaction was performed. Namely, within that period, the buyer is obliged to pay, i.e. the sellers are obliged to transfer the assets to the buyers. This way of settling is inadequate because investors, whose number is already insufficient, in a situation where daily auctions and daily continuous trading take place on the stock exchange, aredirectly exposed to the risk of large losses if stock prices drop during theblocked periods. The introduction of settlement accounts or daily settlement would eliminate a factor that can have a disincentive effect on investors.

Trading in government bonds, but also higher investment activity in the domestic stock market, resulted in excellent total turnover on the Belgrade Stock Exchange, including continual growth of stock exchange indices. 
Trading in shares issued in the privatization process was the initial trigger for more intensive development of the capital market in Serbia. Therefore, the offer by individual owners of shares in the privatization process and bonds obtained on the basis of old foreign currency savings represent the dominant market material on the capital market of the Republic of Serbia. When it comes to demand, investors interested in gaining control over companies are dominating. There are significantly fewer individual investors who want to place surplus funds and achieve a return.It is also evident that the presence of the so-called middle class on the capital market, which gives the market mass, is insufficient. The reason for that is the absence of an investment environment such as the one in countries with developed capital markets, on the one hand, and distrust in market institutions, on the other hand. We have pointed out numerous risks present on the Serbian capital market. It is indisputable that the state should seriously manage the following risks: macroeconomic risks (especially the amount of public debt), (in)stability of the exchange rate, liquidity risk (which is conditioned by the development and size of the stock market measured by market capitalization), interest rate risk, and what is very accentuated - the risks associated with incomplete information about the company's operations and the company's creditworthiness. The major shortcoming of the Belgrade Stock Exchange is the lack of liquid shares. The growth of the market capitalization is the consequence of the growth of the share prices of listed companies, but it is primarily the consequence of the adopted regulations that obliged a large number of companies to "go public". As for other countries in the region, the growth of market capitalization was accompanied by the growth of the social product, and the listing of public companies on the stock exchange is expected to contribute to the growth of GDP. As long as other shares are traded on the over-the-counter market, the Serbian stock market still has a long way to go.

Greater supply of various financial assets, adequate legal protection, publicity of work, adequate information and education could restore confidence in the financial system and increase the presence of individual investors in the capital market. Foreign investors are usually involved in the following: lending on a credit basis, direct investments, portfolio investments. The presence of foreign investors, especially strategic investors, could be a significant boost to the capital market of the Republic of Serbia.

\section{Conclusion}

In order to to ensure adequate capital raising and economic growth of the national economy an efficient capital market is essential.The opportunities that the capital market provides in channeling funds to and from individuals, companies, corporations, institutions and other economic and legal entities in different countries have been used differently. Not only does it depend on the current legal regulations, but also on the habits, traditions and expectations of financial market actors. 
The Republic of Serbia has been in a period of radical changes in both economic and financial system for many years. As a country with an underdeveloped market economy, it seeks to provide the missing financial resources for economic development from foreign sources, new investments as well as portfolio investments (sale of existing capacities).Although the missing funds provision strategy is based on bank loans and the credit market, however, it relies predominantly on the securities market.After creating legal and institutional preconditions for the formation and operation of the securities market and its activation and involvement of foreign investors, today it is not a country with an underdeveloped market economy and capital market, but a country known for its "young" emerging capital market. The underdeveloped capital market is one of the reasons for the slow building of a market economy in Serbia. In other words, Serbia has been in the phase of radical reforms of the economic and financial system for many years. Capital market development, in the context of general reforms, should be implemented as soon as possible. Countries that do so will find it easier to swallow the bitter pill of transition. It also implies shorter negative effects on the road to lasting recovery of their economies.

\section{References:}

1. Bernard J. Foley: Capital market, Macmillan Education LtdLondon, 1991.

2. Brzaković, T: Determinante izbora investicionih strategija banaka na tržištu kapitala, Ekonomski fakultet, Niš, 2006.
(Brzaković, T: Determinants of the choice of investment strategies of banks in the capital market, Faculty of Economics, Nis, 2006.)

3. Erić, Dejan: Finansijska tržišta i instrumenti, Naučna knjiga, 1997. (Erić, Dejan: Financial Markets and Instruments, Naucna knjiga, 1997)

4. Grupa autora: Tržište novca i tržište kapitala u Jugoslaviji, Udruženje banaka Jugoslavije, Beograd, 1990. (Group of authors: Money Market and Capital Market in Yugoslavia, Association of Yugoslav Banks, Belgrade, 1990)

5. Hyman, D., Public Finance - A Contemporary Application of Theory to Policy, Thomson, 2008.

6. Narodna banka Srbije (2018) Međunarodna investiciona pozicija Republike Srbije, Beograd. (The National Bank of Serbia (2018) International Investment Position of the Republic of Serbia, Belgrade.)

7. Robert G. Henstrom „Voren Bafet za sva vremena: principi stari, ekonomija nova“" Plato, 2006. (The Essential Buffett: Timeless Principles for the New Economy)

8. Robinson, J., Economic Philosophy, Pelican Books, London, 1964.

9. Simoneti, M., Kawalec, S. (1995) Bank rehabilitation and enterprise reststructuring. Ljubljana: CEEPN.

10. Šoškić, D., "Securities: portfolio management and investment funds", Faculty of Economics, Belgrade, 2006. (Šoškić, D., „Hartije od vrednosti: upravljanje portfolijom i investicioni fondovi“, Ekonomski fakultet Beograd, 2006.)

11. Vasiljević, B., Osnovi finansijskog tržišta, DH, Beograd, 1997. (Vasiljevic, Branko: Fundamentals of the financial market, DH, Belgrade, 1997)

12. Živković, A., Kožetinac, G. Monetarna ekonomija, Ekonomski fakultet Beograd, Beograd 2016. (Živković, A., Kožetinac, G., Monetary Economics, Faculty of Economics, Belgrade, Belgrade 2016.) 